\title{
Wastewater and Septic System Management for the COVID-19 Virus: Frequently Asked Questions ${ }^{1}$
}

Mary G. Lusk²

\section{Introduction}

Coronavirus disease (COVID-19) is a lung infection primarily spread via respiratory droplets produced by coughing and sneezing or through direct contact with infected individuals. The virus that causes COVID-19 can be excreted in the feces of infected persons. Viral fragments have been found in fecal matter of infected individuals, and one research group was able to culture the virus from stool samples in a laboratory setting, indicating that the infectious virus may be present in the stool of COVID-19 patients (WHO 2020). This document answers common questions about the potential role of wastewater and septic systems in transmission of COVID-19. This document is intended as guidance for the general public.

\section{Does wastewater play a role in COVID-19 transmission?}

As of April 2020, the World Health Organization (WHO) reported no known cases of COVID-19 transmission via contact with infected feces, and they state that the risk of COVID-19 transmission via contact with feces is low (WHO 2020). The WHO further states that there is no evidence that COVID-19 has been spread by sewage (wastewater) systems. This is true even for places in the world without highly developed sewage treatment capabilities.
The WHO recommends that infected individuals have their own toilet that is not shared with others in the household and that toilets should be flushed with the lid down to prevent droplet splatter. Caregivers for infected individuals should practice good handwashing hygiene after contact with an infected person's waste. This includes washing hands with soap for 40-60 seconds.

\section{Do wastewater treatment plants treat COVID-19?}

During the wastewater treatment process, solids are settled out and the treated wastewater is then disinfected. The standard treatment and disinfection at a wastewater treatment plant is carried out by chlorination or with ultraviolet (UV) light and is considered effective for removing the virus from the waste stream. According to Florida Administrative Code rulemaking, "all wastewater treatment facilities shall be designed and operated to provide the level of disinfection necessary to protect health [from] microbiological pollutants" (Rule 62-600.440(1), F. A. C.). Almost all wastewater treatment plants in Florida rely on chlorination to disinfect wastewater.

1. This document is SL479, one of a series of the Department of Soil and Water Sciences, UF/IFAS Extension. Original publication date September 2020. Visit the EDIS website at https://edis.ifas.ufl.edu.

2. Mary G. Lusk, assistant professor, urban water quality, Department of Soil and Water Sciences, UF/IFAS Gulf Coast Research and Education Center, Wimauma, FL.

The Institute of Food and Agricultural Sciences (IFAS) is an Equal Opportunity Institution authorized to provide research, educational information and other services

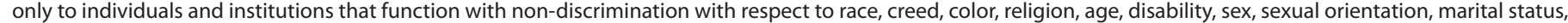

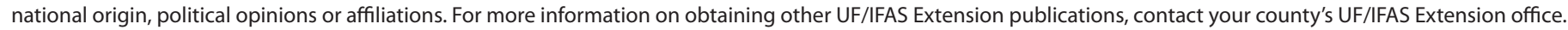
U.S. Department of Agriculture, UF/IFAS Extension Service, University of Florida, IFAS, Florida A \& M University Cooperative Extension Program, and Boards of County Commissioners Cooperating. Nick T. Place, dean for UF/IFAS Extension. 


\section{Could COVID-19 be in the reclaimed water I used to irrigate my lawn?}

Once domestic wastewater is treated at the wastewater treatment plant, it can be safely discharged to a stream, or it can be returned to communities for reuse. This reuse water is reclaimed water and must undergo "high level disinfection" at the wastewater treatment plant (Rule 62-600.440(5), F. A. C.). High level disinfection requires that the treated wastewater is filtered and then disinfected so that fecal coliform bacteria are reduced to below detection levels. Thus, there is virtually no risk that reclaimed water can be a source of fecal-borne virus transmission. However, out of an abundance of caution, reclaimed water should be applied when there is minimal risk of human exposure, and it should never be used to fill pools or children's toys. Public and private spaces outside your home that use reclaimed water can be identified by the purple pipes that are used to convey reclaimed water. For more information on reclaimed water and precautions for its use in the landscape, see SL338 (https://edis.ifas.ufl.edu/ss543) and SL339 (https://edis.ifas.ufl.edu/ss544).

\section{Will my septic system remove COVID-19?}

The US Environmental Protection Agency (EPA) states that a properly managed septic system (one that has been sited according to law in appropriate soils and is regularly inspected by certified professionals) can safely manage viruses found in wastewater, including the COVID-19 virus (US EPA 2020). Many viruses are treated and removed in the septic system drainfield (Figure 1). As the effluent moves through the drainfield soil, viral particles are destroyed or filtered out of the water (Lusk, Toor, and Obreza 2011a, 2011b). Viruses are best treated by septic systems when the systems have been placed in appropriate soils, under guidelines set forth by the state law. Also, septic systems must be sited a minimum distance from drinkingwater wells, thus reducing any chance for pathogens from septic system waste to enter drinking-water sources. For more information about how septic systems treat a variety of viruses, see SL351 (https://edis.ifas.ufl.edu/ss553). For more information about how septic systems work, see SL347 (https://edis.ifas.ufl.edu/ss549).

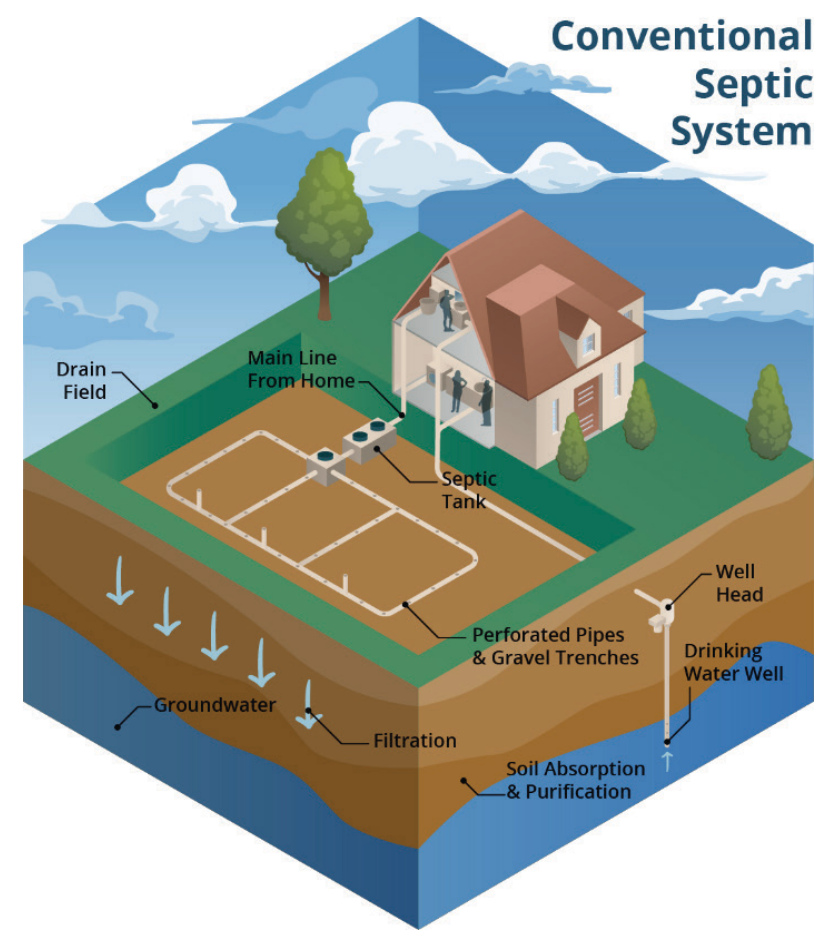

Figure 1. A conventional septic system consisting of a septic tank and drainfield. The septic tank is buried in the soil and collects household waste. As waste collects in the septic tank, solids settle to the bottom of it and the liquid (called effluent) flows out to the drainfield, or soil area through which effluent percolates downward. Credits: UF/IFAS GCREC Soil and Water Quality Lab

\section{Are there special considerations for septic system maintenance during a coronavirus outbreak?}

During the 2020 COVID-19 outbreak, there were widespread shortages of toilet paper that led to a sudden increase in the use of "flushable wipes." At the same time, many people used increased numbers of disinfecting wipes to clean household surfaces, and these wipes were sometimes disposed of by flushing down the toilet. However, disinfecting wipes and even personal hygiene wipes labeled as "flushable" do not break down in sewer or septic systems and can damage a home's plumbing system. When these items are flushed, they can clog toilets or create sewage backups in your home and community. Therefore, the only things that should be flushed are human waste and toilet paper (Figure 2). 


\section{Think Before You Flush}

Flush ONLY toilet paper and human waste.

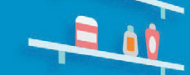

- Toilet paper is designed to

disintegrate in water.

- DONPT FLUSH

$X$ napkins

$x$ wipes

$X$ paper towels

$x$ cotton balls

x "Flushable" wipes

These items can cause pipe

blockages in septic systems

and central sewer facilities,

potentially causing sewage

backups in your home and

the need for costly repairs.

UFIIFAS

Figure 2. Wipes, including "flushable wipes," can clog septic systems and public sewers and cause sewage backups in your home.

Credits: Tracy Bryant, UF/IFAS Communications

\section{References}

Lusk, M. G., G. S. Toor, and T. Obreza. 2011a. Onsite Sewage Treatment and Disposal Systems: Bacteria and Protozoa. SL350. Gainesville: University of Florida Institute of Food and Agricultural Sciences. https://edis.ifas.ufl.edu/ss552.

Lusk, M. G., G. S. Toor, and T. Obreza. 2011b. Onsite Sewage Treatment and Disposal Systems: Viruses. SL351. Gainesville: University of Florida Institute of Food and Agricultural Sciences. https://edis.ifas.ufl.edu/ss553.

US EPA. 2020. "Can I Get COVID-19 from Wastewater or Sewage?” https://www.epa.gov/coronavirus/ can-i-get-covid-19-wastewater-or-sewage.

World Health Organization. 2020. Water, Sanitation, Hygiene, and Waste Management for the COVID-19 Virus: Interim Guidance, 23 April 2020. 